\title{
WHY PROFESSOR LESSIG'S “DEPENDENCE CORRUPTION” IS NOT A FOUNDING-ERA CONCEPT
}

\author{
Seth Barrett Tillman*
}

The Supreme Court is again tasked with deciding the constitutionality of the statutory regime regulating federal elections. In 2010, in Citizens United v. Federal Election Commission, ${ }^{1}$ the Court, in a 5 to 4 vote, struck down key provisions of the Bipartisan Campaign Reform Act, i.e., the provisions regulating independent expenditures by corporations and labor unions. This term, in McCutcheon v. Federal Election Commission, ${ }^{2}$ the Court will decide whether aggregate contribution limits set by federal statute pass constitutional muster.

A recent line of highly original scholarship, first promoted by Professor Zephyr Teachout in 2009, argued that the Constitution embodied a nontextual anti-corruption principle, inhering in the Constitution's structure, which (potentially) trumped First Amendment concerns in the elections context. ${ }^{3}$ Correct or not, Teachout's constitutional vision was, broadly speaking, an originalist one. By contrast, Professor Lawrence Lessig argues that in deciding McCutcheon, the Court should be guided by its prior decision in Buckley v. Valeo. ${ }^{4}$ In Buckley, the Court held that the government's interest in preventing actual corruption or the appearance of corruption outweighed competing First Amendment interests, and for that reason the Buckley Court upheld federal statutory campaign contribution limits. To be sure, Buckley was not an "originalist" opinion: the Court did not assert that its "corruption" rationale was part of the Framers' eighteenth century plan. Professor Lessig argues that when deciding the reach of Buckley's corruption rationale, the Court should be guided by the Framers' understanding of "corruption," as opposed to the modern one announced in Buckley. ${ }^{5}$ Lessig's position has been criticized on theoretical grounds: it is neither

\footnotetext{
* Lecturer, Department of Law, National University of Ireland Maynooth. An earlier version of this Essay was first published as: Seth Barrett Tillman, Why Professor Lessig's "Dependence Corruption" Is Not A Founding-Era Concept?, NATIONAL CONSTITUTION CENTER CONSTITUTION DAILY (Oct. 23, 2013, 7:00 AM), http://blog.constitutioncenter.org/2013/10/why-lessigs-dependence-corruption-isnot-a-founding-era-concept/, also available at $\mathrm{http}: / / \mathrm{ssrn}$.com/abstract=2342945.

${ }^{1} 558$ U.S. 310 (2010) (Kennedy, J.).

${ }^{2} 893$ F. Supp. 2d 133 (D.D.C. 2012) (Brown, J., for unanimous three-judge panel), prob. juris. noted, 133 S. Ct. 1242, 1242 (U.S. Feb. 19, 2013) (No. 12-536). Oral argument before the Supreme Court of the United States was held on October 8, 2013. At the time this Essay was written, the Supreme Court had not yet issued an opinion.

${ }^{3}$ See Zephyr Teachout, The Anti-Corruption Principle, 94 CORNELl L. REv. 341 (2009).

${ }^{4} 424$ U.S. 1 (1976) (per curiam).

${ }^{5}$ See, e.g., Lawrence Lessig, More on an "originalist” understanding of "corruption," LESSIG BLOG, v2 (Oct. 1, 2013), http://lessig.tumblr.com/post/62798050073/more-on-an-originalist-understandingof-corruption ("Reading 'corruption' as the Framers would have would not force the Court to reverse any decision it has already made. It would not, for example, undermine Citizens United. So again, the consistent originalist is not constrained to ignore the Framers [sic] view. Which is again why s/he should follow them - if consistency is the charge." (italics added)); Lawrence Lessig, On "originalism" and the First Amendment (or alternatively, "please don't throw me into the briar
} 
wholly modern (per Buckley), nor wholly originalist (in any traditional sense). I will leave those abstract methodological concerns to others. Here, what is important to note is that both Lessig and Teachout agree that they have identified a stable, unified meaning as to how the Framers (and the public during the Framers' era) understood corruption in relation to the Constitution of 1787-1788: the Constitution of the Framers and Ratifiers.

I contest their position: no such unified concept existed in $1787-1788 .{ }^{6}$ And if it did exist, Lessig and Teachout have failed to excavate its details from our long lost past; they have failed to delineate the concept's contours; and they have failed to explain its precise implications for election law and, more importantly, for all (or, indeed, any) of the other areas of law which any such newly resurrected constitutional concept would necessarily impinge on.

\section{Corruption and the Constitution's Text}

Most theories of constitutional interpretation start with the text. And, of course, the Constitution's text speaks directly about corruption. The Impeachment Clause ${ }^{7}$ states that the President, Vice President and all civil officers of the United States are subject to impeachment for "treason, bribery, or corruption." You remember studying that in secondary school, right?

Actually, you probably do not remember it, and for good reason, it is not in the Constitution - at least, not anymore. "Corruption" appeared in a preliminary draft of the Constitution's Impeachment Clause. But this language was dropped, and superseded by "treason, bribery, and maladministration," but the "maladministration" language appeared too vague. ${ }^{8}$ The Convention did not return to the earlier "corruption" language, and instead, it chose "treason, bribery, or other high crimes and misdemeanors." We do not know precisely why the Framers dropped the original "corruption" language. ${ }^{9}$ Richard J. Ellis, a period historian, has suggested that "corruption" was dropped because "corruption"-like "maladministration"-was too vague. ${ }^{10}$ If Ellis is correct, then Lessig's position is not tenable. If the Framers did not

patch"), LESSIG BLOG, V2 (Oct. 15, 2013), http://lessig.tumblr.com/post/64118233712/onoriginalism-and-the-first-amendment-or ("I don't see how an 'honest originalist' avoids cabining his conception of 'corruption' in light of the Framers' values.").

${ }^{6}$ See Seth Barrett Tillman, Opening Statement, Citizens United and the Scope of Professor Teachout's Anti-Corruption Principle, 107 Nw. U. L. REV. 399 (2012).

${ }^{7}$ U.S. CONST. art. II, § 4 ("The President, Vice President and all civil Officers of the United States, shall be removed from Office on Impeachment for, and Conviction of, Treason, Bribery, or other high Crimes and Misdemeanors." (emphasis added)).

${ }^{8}$ See William M. Meigs, The Growth of the Constitution in the Federal Convention OF 1787, at 233-34 (Philadelphia, J.B. Lippincott Co. 2d ed. 1900).

${ }^{9}$ See, e.g., Teachout, supra note 3, at 367 ("There is no explanation for why the term 'corruption' was taken out, suggesting that a committee on style or form removed it, but I have not been able to uncover the real reason ...." (emphasis added)).

${ }^{10}$ See Richard J. ElLIS, FOUNDING THE AMERICAN PRESIDENCY 238-39 (1999). 
think the corruption concept had sufficient clarity in 1787, then we cannot create that clarity today, at least, we cannot do so in the Framers' name.

But even if Ellis is wrong, even if "corruption" was dropped for some other reason, it does not matter. What matters (that is, what should matter) is that the Framers put "corruption" in the Constitution's text, but they then chose to take it out, and even failed to put it back in when they had a clear opportunity to do so. Thus, the Constitution's plain text and its drafting history pose a direct challenge to Lessig's and Teachout's position, but it is not a challenge either has ever meaningfully dealt with - although each has had repeated opportunities to do so. ${ }^{11}$

Let's be clear. Lessig and Teachout are asking us to embrace corruption as the key concept espoused by the Framers of the Constitution (and of the Bill of Rights). But when the Framers had a chance (actually multiple chances) to give this concept prominence in the Constitution's actual text, the Framers chose not to do so. It is not as if they forgot to use this term or, instead, used some close synonym; rather, they actively took this term out of the Constitution. So why should we today embrace the corruption concept as one having constitutional scope or dimension? And, more importantly, how can Lessig or Teachout ask us to do so as an exercise in originalism or in the name of the long-dead Framers?

\section{James Madison's Federalist No. 52: "Dependent on the People Alone"}

In his McCutcheon brief, Professor Lessig argues that the Framers had "a very specific conception of the term "corruption'." In other words, the Framers sought to craft government institutions in which officials, in particular members of the House and the President, avoided "improper dependencies" and, instead, were "dependent on the people alone." 13

Turing to the Incompatibility Clause as an example, Professor Lessig explains: "the Framers blocked an improper dependence of the legislature upon the Executive, by banning legislators from serving [concurrently] as executive officers." 14 I agree that the purpose of the Incompatibility Clause was to prevent members of Congress

\footnotetext{
${ }^{11}$ See, e.g., Teachout, supra note 9. I am not suggesting that Professors Lessig and Teachout are in agreement on every aspect of their corruption-related research. See generally infra notes $13 \& 29$.

${ }^{12}$ Brief Amicus Curiae of Professor Lawrence Lessig in Support of Appellee ("Lessig Brief") at 2, McCutcheon v. Federal Election Commission, No. 12-536 (U.S. July 25, 2013), 2013 WL 3874388, at *2 ("The Framers had a very specific conception of the term 'corruption' in mind, one at odds with McCutcheon's more modern understanding of that term.") (filed by the Constitutional Accountability Center).

${ }^{13}$ Id. at $3 \& 8$ (quoting The Federalist No. 52, at 294 (James Madison) (Clinton Rossiter ed., 2003)); Lawrence Lessig, What an Originalist Would Understand 'Corruption' to Mean, 102 CALIF. L. REV. 1 passim (2014). But cf. id. at 5 n.12 (distinguishing Professor Zephyr Teachout's position from Tillman's position); Yasmin Dawood, Classifying Corruption, 9 DUKE J. CONST. L. \& PUB. POL'Y (forthcoming circa June 2014) (manuscript at 10-13) (distinguishing Teachout's position from Lessig's), available at http://ssrn.com/abstract=2401297.

${ }^{14}$ Lawrence Lessig, A Reply to Professor Hasen, 126 HARV. L. REV. F. 61, 70 (2012); cf. Lessig Brief, supra note 12, at 11 (citing the Ineligibility Clause).
} 
from being dependent on the President (at least in regard to holding concurrent federal office). But that limited purpose hardly establishes that the Incompatibility Clause was an exemplar of a higher level purpose to ensure that members were dependent "on the people alone." If the latter really had been the Framers' goal, then the Framers would have actively blocked many other dependencies, and this they did not do.

For example, nothing in the Constitution prevents members from concurrently holding state offices, even those within the appointment power of state governors (acting with or without a council). Indeed, in the First Congress, several members also held state legislative seats, and other members held state judicial and executive offices. ${ }^{15}$ These latter members of Congress were not dependent "on the people alone"- they were dependent on state government appointments, salaries, and sinecures.

Likewise, in terms of setting Congress' initial salary in 1789 or any subsequent raise, each House was dependent on the other House, and both Houses were dependent (absent a veto-proof majority in both Houses) on the President. ${ }^{16}$ It is very difficult to square this salary-related dependence with the scrupulous care the Framers took to ensure member independence in regard to concurrent federal office-holding. Why the different treatment? If the Incompatibility Clause is rooted in maintaining members' independence vis-à-vis the President, then why was the independence concern set aside when members' very salaries were in play? Maybe this question has an answer, but it is not one Professor Lessig has shared with us. And without a good answer, we cannot simply assume that the Framers' global purpose was to preserve members' dependence "on the people alone."

Finally, nothing in the Constitution prevents members of Congress (or, even, the President) from concurrently holding interests in private (domestic or foreign) commercial entities. Members of Congress are not constitutionally precluded from holding interests in private entities with litigation before the federal courts. Likewise, members are not precluded from personally acting as private attorneys for such entities in litigation before the federal courts. Indeed, members are not constitutionally precluded from holding interests in commercial entities doing business or seeking contracts with the federal government. In all these situations, the members are dependent on someone or some entity other than "the people alone." In short, our Constitution, the Constitution of 1787, banned certain dependencies, but it left others (presumptively) permitted or, at least, strangely unresolved.

\footnotetext{
${ }^{15}$ See Seth Barrett Tillman, supra note 6, at 405-08 (collecting authority); see also Seth Barrett Tillman, Closing Statement, The Original Public Meaning of the Foreign Emoluments Clause: A Reply to Professor Zephyr Teachout, 107 Nw. U. L. ReV. COLLOQUY 180, 195-200 (2013) (same).

${ }^{16}$ See U.S. CONST. art. I, § 6, cl. 1 ("The Senators and Representatives shall receive a Compensation for their Services, to be ascertained by Law, and paid out of the Treasury of the United States."); U.S. CONST. art. I, § 7, cl. 2 (Presentment and Veto Clause). But cf. U.S. CONST. amend. XXVII ("No law, varying the compensation for the services of the Senators and Representatives, shall take effect, until an election of Representatives shall have intervened."). The Twenty-Seventh Amendment was proposed by Congress in 1789, but it was not ratified by three-quarters of the states until 1992. See Michael Stokes Paulsen, A General Theory of Article V: The Constitutional Lessons of the Twentyseventh Amendment, 103 YALE L.J. 677 (1993).
} 
In these circumstances, it is difficult to see how Professor Lessig can tease out, from the very uneven constitutional text, his "very specific" Framing-era conception of corruption-demanding elected-official dependence "on the people alone."

\section{The Foreign Emoluments Clause}

[N]o Person holding any Office of Profit or Trust under the[] [United States], shall, without the Consent of the Congress, accept of any present, Emolument, Office, or Title, of any kind whatever, from any King, Prince, or foreign State.

\section{-U.S. Constitution Article I, Section 9, Clause 8}

In regard to the Foreign Emoluments Clause, Professor Lessig writes: "And most relevant to the conception of 'dependence corruption' that I have advanced here: the Framers banned members [of Congress] from receiving 'any present, Emolument, Office, or Title, of any kind whatever, from any King, Prince, or foreign State' without the consent of Congress." ${ }^{17}$ For the reasons I explain below, Professor Lessig's direct and systematic reliance on the Foreign Emoluments Clause is problematic. $^{18}$

First, state offices are again a significant problem: the Foreign Emoluments Clause does not apply to state positions. Indeed, this clause had a predecessor in the Articles of Confederation, but the earlier confederation incarnation of this clause

\footnotetext{
${ }^{17}$ Lessig, A Reply to Professor Hasen, supra note 14, at 70 (quoting the Foreign Emoluments Clause) (emphasis added).

${ }^{18}$ See id.; Lessig Brief, supra note 12, at 12-14 (same); see also LAWRENCE LESSIG, REPUBLIC, LOST: HOW MONEY CORRUPTS CONGRESS-AND A PLAN TO STOP IT 18 (2011) (expounding on the Foreign Emoluments Clause, and its historical genesis during the confederation period, with particular reference to members of Congress); id. ("The core corruption the Framers wanted to avoid was Parliament's loss of independence...." (emphasis added)). For example, Professor Lessig writes that the "the Framers didn't want a Congress that was a farm league for the French Riviera." Lessig, $A$ Reply to Professor Hasen, supra note 14, at 70. I very much doubt that the Framers' congressional corruption concerns (such as those they actually held) were rooted in images of the "French Riviera" or sports teams' "farm leagues." My comment is not meant to be snarky, but to remind one that it is all too easy to project our modern vision on the now silent Framers and call our vision their own. The danger of such presentism is not just that we might misunderstood the past, but that we might also fail to fairly value how understanding the actual past might benefit our shared present. Compare, e.g., THE FEDERALIST NO. 55, at 342 (James Madison) (Clinton Rossiter ed., 1961) ("From what quarter can the danger proceed? Are we afraid of foreign gold? If foreign gold could so easily corrupt our federal rulers and enable them to ensnare and betray their constituents, how has it happened that we are at this time a free and independent nation? ... Yet we know by happy experience that the public trust was not betrayed [by the Articles Congress]; nor has the purity of our public councils in this particular ever suffered, even from the whispers of calumny."), with LESSIG, REPUBLIC, LOST, supra at 18 ("Imagine a young democracy, its legislators passionate and eager to serve their new republic. A neighboring king begins to send the legislators gifts. ... Soon the legislators have a life that depends, in part at least, upon those gifts. . . Just such a dynamic was the fear that led our Framers to add to our Constitution ... . A Article I, section 9, clause 8 ....").
} 
expressly applied to both state and federal positions. ${ }^{19}$ So the Constitution of 1787 , our constitution, liberalized the foreign government gift-giving regime. Keep in mind that under the Constitution of 1787, state legislatures: (i) had the power to call Article $\mathrm{V}$ conventions and to ratify proposed constitutional amendments; ${ }^{20}$ (ii) had the power to choose United States senators; ${ }^{21}$ and (iii) also had the power to directly select presidential electors, ${ }^{22}$ a power they sometimes exercised. Similarly, state governors, then and now, had and have the power to fill vacancies in the Senate, at least in certain circumstances. $^{23}$ (And, although the question is not entirely free from doubt, there is good reason to believe that neither the Foreign Emoluments Clause nor its "office" language reach federal electors. ${ }^{24}$ ) Why did the Framers permit foreign governments

${ }^{19}$ Compare ARTICLES OF CONFEDERATION of 1781, art. VI, cl. 1 (" $[\mathrm{N}]$ or shall any person holding any office of profit or trust under the United States, or any of them, accept any present, emolument, office or title of any kind whatever from any King, Prince or foreign State...." (emphasis added)), with U.S. CONST. art. I, § 9, cl. 8 ("[N]o Person holding any Office of Profit or Trust under the[] [United States], shall, without the Consent of the Congress, accept of any present, Emolument, Office, or Title, of any kind whatever, from any King, Prince, or foreign State." (emphasis added)), and Seth Barrett Tillman, The Original Public Meaning of the Foreign Emoluments Clause, supra note 15, at 195-98 (discussing inapplicability of the Foreign Emoluments Clause to state offices), 201-03 (same). Note that the Constitution permits a federal officer to accept a foreign government's gift if the officer has congressional consent. But, no such language appeared in the coordinate provision in the Articles of Confederation. In short, here too, the Constitution of 1787 liberalized the foreign government gift-giving regime. See id. at 204-06 (discussing congressional consent).

${ }^{20}$ See U.S. CONST. art. V.

${ }^{21}$ See U.S. CONST. art. I, § 3, cl. 1 ("The Senate of the United States shall be composed of two Senators from each State, chosen by the Legislature thereof ...."), amended by U.S. CONST. amend. XVII, cl. 1 (mandating direct election of senators).

${ }^{22}$ See U.S. CONST. art. II, § 1, cl. 1 ("Each State shall appoint, in such Manner as the Legislature thereof may direct, a Number of Electors, equal to the whole Number of Senators and Representatives to which the State may be entitled in the Congress ...."), amended by U.S. CONST. amend. XII (mandating separate elector votes for President and Vice President); $c f$. Bush v. Gore, 531 U.S. 98, 113-15 (2000) (Rehnquist, C.J., concurring).

${ }^{23}$ See U.S. ConsT. art. I, § 3, cl. 2 ("[I]f Vacancies [in the U.S. Senate] happen by Resignation, or otherwise, during the Recess of the Legislature of any State, the Executive thereof may make temporary Appointments until the next Meeting of the Legislature, which shall then fill such Vacancies."), amended by U.S. CONST. amend. XVII, § 2 ("When vacancies happen in the representation of any State in the Senate, the executive authority of such State shall issue writs of election to fill such vacancies: Provided, That the legislature of any State may empower the executive thereof to make temporary appointments until the people fill the vacancies by election as the legislature may direct."). It appears that, on occasion, governors have used this power to appoint themselves to vacant Senate seats. See Ken Rudin, When Governors Appoint Themselves To The Senate, NPR: POLITICAL JUNKIE (Sept. 8, 2009, 3:54 PM), http://www.npr.org/blogs/politicaljunkie/2009/09/when_governors_appoint_themsel.html.

${ }^{24}$ In United States v. Hartwell, 73 U.S. 385 (1867) (Swayne, J.), the Supreme Court explained: "The term ["office"] embraces the ideas of [1] tenure, [2] duration, [3] emolument, and [4] duties." Id. at 393 (emphasis added). First, the position of elector is temporary: it lacks meaningful duration - the position ceases once the electors vote for President and Vice President. Second, no federal statute grants the position of elector any emoluments. Third, an elector has only a single discretionary dutyto vote for President and Vice President, as opposed to multiple duties (as required by Hartwell). Finally, whether an elector has tenure remains unclear, but some judicial authority suggests the 
to give gifts to state officials ${ }^{25}$ (and to federal electors), if, as Professor Lessig argues, they were trying to create a constitutional order in which improper foreign dependencies were minimized?

Second, Professor Lessig assumes that the Foreign Emoluments Clause (that is, its "office ... under the United States" language) applies to members of Congress. He offers no support, argument, or evidence for his position. However, the text of the Constitution strongly suggests otherwise. For example, the Elector Incompatibility Clause states: "[N]o Senator or Representative, or Person holding an Office of Trust or Profit under the United States, shall be appointed an Elector." ${ }^{26}$ Now it is possible that the language of the Elector Incompatibility Clause is redundant, and that the "Office... under the United States" language also includes senators and representatives. But the alternative reading is simpler: senator, representative, and "Office ... under the United States" are three distinct categories. Indeed, the strong consensus today among legal academics is that the Constitution embraces a hard distinction between, on the one hand, rank-and-file members of Congress, and, on the other hand, officers affiliated with the Executive and Judicial Branches. ${ }^{27}$ In other words, members are not officers as those terms are used in the Constitution of 1787. Professor Lessig needs to give us a reason to believe that members of Congress are

position lacks tenure. See McPherson v. Blacker, 146 U.S. 1, 35 (1892) (Fuller, C.J.) ("Whatever provisions may be made by statute, or by the state constitution, to choose electors by the people, there is no doubt of the right of the legislature to resume the power at any time, for it can neither be taken away nor abdicated." (emphasis added)).

Alternatively, if electors are not properly characterized as "officers under the United States," but are, instead, better characterized either as state officers or holders of Article VI "public trusts under the United States," than the Foreign Emoluments Clause simply does not apply to the position of elector. See, e.g., Vasan Kesavan, The Very Faithless Elector?, 104 W. VA. L. REV. 123 passim (2001) (hypothesizing that federal electors are not officers "of" or "under" the United States, and are, instead, holders of "public trusts under the United States" per Article VI); Beverly J. Ross \& William Josephson, The Electoral College and the Popular Vote, 12 J. LAW \& POLITICS 665, 692 (2002) ("Relevant constitutional provisions imply that electors are state, not federal, officers.").

${ }^{25}$ Just as the Foreign Emoluments Clause does not apply to members of state legislatures and to state governors, the Foreign Emoluments Clause does not apply either to other state executive branch officials (including those charged with executing federal law or protecting federal interests) or to state judges (who could rule on issues, claims, and defenses arising under federal law). See 4 JOHN BASSETT MoORE, A DigeST OF INTERNATIONAL LAW § 651, at 577 (1906) ("The provisions of the Constitution "neither prevent nor authorize persons who may hold office under any one of the States from accepting an appointment under a foreign government." (quoting State Department correspondence from 1872)); cf., e.g., THE FEDERALIST No. 36, at 227-28 (Alexander Hamilton) (Jacob E. Cooke ed., 1961) (explaining that the Constitution would "enable the [federal] government to employ the ordinary magistracy of each [state], in the execution of its laws").

${ }^{26}$ U.S. CONST. art. II, $\S 1$, cl. 2 (Elector Incompatibility Clause). Likewise, the text of the Incompatibility Clause also suggests that membership in Congress and holding office under the United States are distinct categories. See U.S. ConST. art. I, § 6, cl. 2 ("[N]o Person holding any Office under the United States, shall be a Member of either House during his Continuance in Office." (emphasis added)).

${ }^{27}$ See, e.g., Akhil Reed Amar \& Vikram David Amar, Is the Presidential Succession Law Constitutional?, 48 STAN. L. REV. 113 (1995). 
subsumed under the Foreign Emoluments Clause's "office" language. But he never does.

Indeed, Professor Lessig must do more than proffer "a reason" to believe that the Constitution's and, more specifically, the Foreign Emolument Clause's "office" language reach members of Congress. Rather, he must show that his reading of the Constitution is the best originalist reading ${ }^{28}$ - one consistent with his extraordinary claim that " $[t]$ he Framers had a very specific conception of the term 'corruption'.",29 My own view is that merely acknowledging Framing-era diversity on this longstanding interpretive question (i.e., the scope of the Constitution's "office" language) would seriously undermine Professor Lessig's position. And is it really surprising that the Framers and their contemporaries expressed complex, nuanced, and diverse views on this subject? $?^{30}$

\footnotetext{
${ }^{28}$ Cf. McDonald v. City of Chicago, 561 U.S. 3025, 3072 (2010) (Thomas, J., concurring in part and concurring in the judgment) ("When interpreting constitutional text, the goal is to discern the most likely public understanding of a particular provision at the time it was adopted." (emphasis added)); Amar \& Amar, supra note 27, at 136 n.143 ("The Constitution must mean something - the best reading of the document either permits or bars legislative succession.").

${ }^{29}$ Lessig Brief, supra note 12, at 2 (emphasis added). I think it interesting to note that Professor Lessig's historical claim in this regard is somewhat different from the position put forward by Professor Zephyr Teachout. Lessig has argued that the Framers had "a very specific conception of the term 'corruption'." Id. By contrast, Teachout has argued that the Framers embraced a family of corruption-related conceptions. Compare, e.g., Teachout, supra note 3, at 373-74 ("To the [Philadelphia] delegates, political corruption referred to self-serving use of public power for private ends, including, without limitation, bribery, public decisions to serve private wealth made because of dependent relationships, public decisions to serve executive power made because of dependent relationships, and use by public officials of their positions of power to become wealthy." (emphasis added)), with Lessig, A Reply to Professor Hasen, supra note 14, at 70 ("The classical conception of corruption that animated the Framers was not an obsession with the Rod Blagojevichs of the age." (emphasis added) (citing Teachout)), and Lawrence Lessig, On What Being A (Small r) Republican Means, 74 MONT. L. REV. 37, 40 (2013) ("I do not mean Rod Blagojevich corruption-buying and selling public office for personal gain. ... I mean corruption relative to a baseline- the Framers' baseline - for how this nation was to function." (emphasis added)).

${ }^{30}$ Compare, e.g., 3 THE Debates IN THE SEVERAL STATES CONVENTIONS, ON THE AdOPTION OF THE FEDERAL CONSTITUTION 485-86 (Jonathan Elliot ed., Washington, 2d ed. 1836) (illustrating that Edmund Randolph took the position that the Constitution's "office" language reached members of Congress), with James MONROE, ObSERvations UPON THE Proposed Plan OF Federal GOVERNMENT (Petersburg, Hunter \& Prentis 1788), reprinted in 1 THE WRITINGS OF JAMES MonROE 347, 361 (Stanislaus Murray Hamilton ed., New York, G.P. Putnam's Sons 1898) (illustrating that James Monroe took the position that the Constitution's "office" language did not reach members of Congress, and expressly objecting to Randolph's contrary position); compare DEBATES, supra at 202 (illustrating that Randolph thought Senators could be impeached), with MONROE, supra, at 383 ("The persons subject to impeachment, are the President, Vice-President, and all civil officers of the United States, and no others." (emphasis added)), and id. at 398-99 (same); compare, e.g., 3 JOURNAL OF THE HOUSE OF REPRESENTATIVES OF THE UNITED STATES OF AMERICA 72-73 (Washington, Gales \& Seaton 1826) (recording July 7, 1797 House resolution impeaching Senator Blount), with 8 ANNALS OF CONG. 2319 (Washington, Gales \& Seaton 1851) (recording January 11, 1799 Senate adoption of a resolution to the effect that: "this Court ought not to hold jurisdiction" over the Blount impeachment). Indeed, even where the Framers have left us records, modern authorities divide in regard to what was meant. Compare, e.g., MichaEL J.
} 
My own view (albeit, which is not widely shared) is that the Foreign Emoluments Clause's "office ... under the United States" language extends to all positions subject to supervision in the regular course of their duties, including positions created, regularized, or defeasible by federal statute, i.e., subconstitutional, non-elected, or statutory positions in any of the three branches of the federal government, and that this language does not extend to elected or constitutionally mandated positions in any branch. There is an abundance of early American materials supporting this view. ${ }^{31}$

For example, in 1792, the Senate ordered Secretary of the Treasury Alexander Hamilton to draft a financial statement listing all persons holding "office ... under the United States" and their salaries. Hamilton's response, which was roughly ninety manuscript-sized pages, included personnel in each of the three branches of the federal government, including the Legislative Branch, but Hamilton did not include the President, Vice President, Senators, or Representatives. In other words, Hamilton did not include any elected positions in any branch. ${ }^{32}$ Similarly, in 1791, President George Washington received, accepted, and kept a gift from the French ambassador to the United States, but Washington never sought nor received congressional consent to keep this valuable gift. ${ }^{33}$ Washington received, accepted, and kept at least one other such gift during his presidency. ${ }^{34}$ And, here too, he did not ask for or receive congressional consent. These gifts were not a secret; but, I have to yet discover even one anti-administration representative or senator or anyone in the press (or even anyone in private correspondence) who stated that Washington acted corruptly or

GerhardT, The Federal ImPEACHMENT Process: A CONSTITUTIONAL AND Historical ANALYSIS 15 \& 199 n.21 (2d ed. 2000) (citing Federalist No. 66 for the proposition that Hamilton believed that "members of Congress could not be impeached"), with BUCKNER F. MELTON, JR., THE FirST IMPEACHMENT: THE CONSTITUTION'S FRAMERS AND THE CASE OF SENATOR WiLliam BLOUNT 49 \& n.105 (1998) (citing Federalist No. 66 for the proposition that Hamilton believed that legislators were amenable to impeachment); compare, e.g., JOHN E. NOWAK \& RONALD D. ROTUNDA, CONSTITUTIONAL LAW 153 n.9 (8th ed. 2010) ("[W]hen the Senate impeaches someone, it can impose a disqualification for U.S. Representative and Senator, as well as any other office of trust under the United States." (emphasis added)), with Amar \& Amar, supra note 27, at 115 (asserting that "'Officers' of or under the United States thus means certain members of the executive and judicial branches, but not legislators ...." (emphasis added)).

${ }^{31}$ See also, e.g., DAVID A. MCKNIGHT, ThE ElECtORAL SySTEM OF THE UNITED STATES 346 (Philadelphia, J.B. Lippincott \& Co. 1878) ("It is obvious that . . the President is not regarded as 'an officer of, or under, the United States,' but as one branch of 'the Government."' (emphasis added)); cf. State ex rel. Ragsdale v. Walker, 33 S.W. 813, 814 (Mo. 1896) (Macfarlane, J.) ("An office under the state must be one created by the laws of the state. The incumbent must be governed by state laws and must exercise his powers and perform his duties in obedience to a statute of the state." (emphasis added)). Foreign materials also agree. See, e.g., ANNE TwOMEY, THE CONSTITUTION OF NEW SOUTH WALES 438 (2004) ("As it is an elective office, and not generally subject to the direction or supervision of the government, one would assume that it is not an office held 'under the Crown'." (emphasis added)).

${ }^{32}$ See Seth Barrett Tillman, supra note 6, at 410-15.

${ }^{33}$ See id. at $415-17$.

${ }^{34}$ See id. at 415 n. 46. 
wrongfully. Modern originalists — including Professor Lessig ${ }^{35}$ — usually consider the precedents established by President Washington and his administration (including Secretary Hamilton) as strong indicia of the Constitution's original public meaning.

Professor Lessig called the Foreign Emoluments Clause the "most relevant" of all constitutional provisions in regard to his dependence corruption theory. But unless George Washington was corrupt and the whole country silently complicit in his corruption, it seems to follow that the Foreign Emoluments Clause did not (originally) apply to any elected officials, state or federal. And if that is correct, then there is really nothing much left of Professor Lessig's dependence corruption position to salvage.

\section{Preferred Citation Format}

Seth Barrett Tillman, Why Professor Lessig's "Dependence Corruption" is not a Founding-Era Concept, 13 ELECTION L.J. (forthcoming circa June 2014) (peer reviewed), available at http://ssrn.com/abstract=2342945, also available at http://works.bepress.com/seth_barrett_tillman/428/, and NATIONAL CONSTITUTion Center CONSTITUTION DAILY (Oct. 23, 2013, 7:00 AM), http://blog.constitutioncenter.org/2013/10/why-lessigs-dependence-corruption-isnot-a-founding-era-concept/.

\footnotetext{
${ }^{35}$ In his own writings, Professor Lessig has turned to Washington, Hamilton, and precedents set during the Washington administration. See, e.g., Lawrence Lessig \& Cass R. Sunstein, The President and the Administration, 94 ColuM. L. REV. 1, 75 (1994) ("Moreover, nowhere in the debate in Congress is there a suggestion of this constitutional concern [in regard to the Invalid Pensions Act of 1792]. Nor did President Washington indicate that there was anything problematic about the statute as written."); id. at 13 n.42 (explaining "President Washington's self-conception of his role in the legislative process"); id. at 49 ("[N]ot even Hamilton described the Vesting Clause as an independent source of substantive executive power, though he was in general quite eager to define a strong executive."); see also, e.g., id. at 26-27 ("Whatever dispute there may be about the removal power of the President over the Secretary of Foreign Affairs and similar officers, there is no ambiguity about a central point: the first Congress conceived of the proper organizational structure for different executive departments differently. This conception, we believe, argues against the belief in a strongly unitary executive." (footnotes omitted) (citing THE FEDERALIST NO. 77 (Alexander Hamilton))).
} 